\title{
Soil carbon stocks of inceptisols under different land use in the Northern tropical humid region of Honduras
}

\author{
Gusman Catari* and Carlos Rivera
}

National Autonomous University of Honduras, Centro Universitario Regional del Litoral Atlántico (CURLA), Soil Department, Colonia El Búfalo, La Ceiba, Honduras

*Corresponding Author: gusman.catari@unah.edu.hn

\begin{abstract}
Soil organic carbon (SOC) is important in the carbon cycle and studies in the field are gaining relevance because of its relation to global climate change. In this paper, we report a study of SOC stock $(0-200 \mathrm{~cm})$ from a 50 years old secondary forest and a pasture under inceptisols in a floodplain in the tropical humid Caribbean coast of Honduras. Samples were collected at the depths 0-

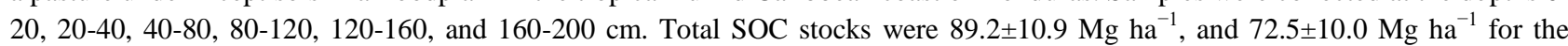
secondary forest and pasture respectively. The estimated annual increase of SOC stock in the forest is $0.34 \mathrm{Mg} \mathrm{C} \mathrm{ha}^{-1} \mathrm{year}^{-1}$. SOC stock values were $50.3 \%$ and $47.9 \%$ of the total $(0-200 \mathrm{~cm})$ in the $0-20 \mathrm{~cm}$ layer for forest and pasture respectively. SOC distribution at a depth of $0-20 \mathrm{~cm}$ were $21.26 \mathrm{~g} \mathrm{~kg}^{-1}$ and $12.09 \mathrm{~g} \mathrm{~kg}^{-1}$ for forest and pasture respectively. Soil texture at the $0-20 \mathrm{~cm}$ depth were clay loam, and sandy clay loam, in the forest and pasture respectively. SOC stock in these ecosystems would be reduced if they were converted back to conventional agriculture, particularly in the forest. The forest had higher SOC values because of higher litter input as compared to the pasture, particularly in the upper soil layers, at deeper layers there are no significant differences $(p<0.05)$ and SOC values are low. Compared to most other studies in tropical regions, SOC stock in our study were lower in both ecosystems, this may be due to high precipitation ( $c a .3200 \mathrm{~mm}_{\text {year }}{ }^{-1}$ ) and high temperatures, rate of decomposition of litter input, general low clay content, and possibly priming effects which we have not addressed. More studies on the SOC stock in Central America with a similar climate are needed to improve our understanding of SOC dynamics and help reducing uncertainty in SOC models.
\end{abstract}

Keywords: Land-use change, Humid tropics, Soil carbon concentration, Inceptisol, Tropical rainforest, Honduras.

\section{INTRODUCTION}

Soil organic matter has received increased attention for its role in the sequestration of $\mathrm{CO}_{2}$ from the atmosphere. In the $\mathrm{C}$ cycle, soil organic carbon (SOC) stock is the largest pool of terrestrial organic carbon, with approximately 2344 $\mathrm{Pg}\left(1 \mathrm{Pg}=10^{15} \mathrm{~g}=10^{9} \mathrm{Mg}\right)$ at the top $300 \mathrm{~cm}$ (Jobbágy \& Jackson, 2000), ca. 3 times larger than the amount of C stored in above-ground plant biomass (Post et al., 1982; Eswaran et al., 1993; Jobággy \& Jackson, 2000). SOC storage is regulated by the balance of C inputs from biomass and outputs through decomposition (Jenny, 1941; Schlesinger, 1977). Tropical soils store about 30\% (384-506 Pg) of the global SOC pool down to $100 \mathrm{~cm}$ depth (Eswaran et al., 1993; Batjes, 1996). It is estimated that about $1.0 \mathrm{Pg} \mathrm{C} \mathrm{yr}^{-1}$ from the soil is emitted as $\mathrm{CO}_{2}$ into the atmosphere, mainly by tropical deforestation (Le Quéré et al., 2013). For the decade of 2009-2018, the annual rate of emission from tropical deforestation and other land-use changes was $1.5 \pm 0.7 \mathrm{Pg} \mathrm{C} \mathrm{yr}^{-1}$ (Lal, 2020).

In the search to identify options to limit the global atmospheric warming to $1.5^{\circ} \mathrm{C}$ (IPCC, 2018) there has been a growing interest in the potential of soils to absorb atmospheric $\mathrm{CO}_{2}$ and mitigate the warming (Houghton, 2005; Lal, 2016; Lal, 2020). Currently, there is an ambitious goal to increase SOC by $0.4 \%$ per year to help mitigate climate change which results from the ratio of total $\mathrm{C}$ emissions to the atmosphere and the total SOC stock, $8.9 \mathrm{Pg} / 2400 \mathrm{Pg}$ (Minasny et al., 2017). In the Paris Accord, stakeholders agreed in a voluntary action plan to implement practices that maintain or enhance SOC stocks (Chambers et al., 2016; Lal, 2016).

Research on SOC in the humid tropics in Latin America, as indicated by the small number of published studies (Powers \& Schlesinger, 2002; Jimenez et al., 2007; Chacón et al., 2015; de Oliveira, 2017) has not kept pace with studies in temperate climates. Research in humid climates indicates that with increase in temperature, rates of production and decomposition of organic matter increase, but the relative increases of the latter are greater (Schlesinger, 1977; Oades, 1988). Field observations of SOC stocks with tropical land-use changes are highly unrepresentative of most tropical landscapes (Powers et al., 2011), in Central America so far, most of the studies were undertaken in Costa Rica as indicated by published studies.

Studies of SOC stock in different regions of the world have traditionally provided results to $100 \mathrm{~cm}$ depth (Jobbágy \& Jackson, 2000) which may be sufficient in most mineral soils because organic $\mathrm{C}$ content declines with an increase in 
soil depth (Scharlemann et al., 2014) and it may facilitate comparison of results but it has the disadvantage that not the whole soil-carbon stock is taken into consideration. Currently, there is the need to quantify SOC stock at deeper layers (Sayer et al., 2019; Lal, 2020). The contribution of carbon in the deep subsoil-below $100 \mathrm{~cm}$ to the total carbon pool is important, particularly, in soils of the tropics which are generally deep to very deep (Sayer et al., 2019). The additional amount of SOC stock contained is $47.4 \%$ in $0-100 \mathrm{~cm}$ and $63.4 \%$ in $0-200 \mathrm{~cm}$ compared to that in the $0-30 \mathrm{~cm}$ layer (Lal, 2020). Even though, some SOC at deeper layers are stable which may not be affected by a change in land use (Sombroek et al., 1993) some proportion of it has a relatively fast turnover and might act as a carbon source if temperature increases (Jobbágy \& Jackson, 2000) and it raises important issues for global carbon budgets and for carbon sequestration strategies (Batjes, 1996).

The general objective of this study was to estimate the SOC stock to $200 \mathrm{~cm}$ depth in a tropical humid region in the Caribbean coast of Honduras under two land uses: a secondary forest (50 years old) and a pasture. The specific objectives were: (1) to determine the distribution of SOC concentration to $200 \mathrm{~cm}$ depth, and (2) to determine SOC stock and their depth distribution to $200 \mathrm{~cm}$.

\section{MATERIALS AND METHODS}

\section{Study area}

This research was undertaken at the Centro Universitario Regional del Litoral Atlántico (CURLA) which is part of the National Autonomous University of Honduras (UNAH), in the Caribbean floodplains of northern Honduras, in La Ceiba Municipality $\left(15^{\circ} 46^{\prime} \mathrm{N}, 86^{\circ} 47^{\prime} \mathrm{W}\right)$. CURLA is located at the outskirts of the La Ceiba city. For the study, two ecosystems located next to each other were selected (Fig. 1). A 50 years old forest (22 ha) consisting mainly of Vochysia guatemalensis Donn. Smith, this area before 1967 was an agricultural land dedicated to monocrops. The second site is a pasture area $(1.5 \mathrm{ha})$ located next to the forest, it has been pasture for approximately the last 10 years, before that it was devoted to agriculture. In the Holdridge system the area is classified as tropical wet forest. The elevation is approximately $5 \mathrm{~m}$ a.s.1. and slope is less than $2 \%$. Soils are classified as inceptisols (Typic Dystrudepts) under the USDA Soil Taxonomy classification system, the soil parent materials are derived from Quaternary alluvial deposits (Weyl, 1980). Over the period 1972-2018, annual precipitation averaged $3176 \mathrm{~mm}$. Monthly precipitation is $264 \mathrm{~mm}$, November is the wettest month with an average of $542 \mathrm{~mm}$, and the less rainy month is May with an average of $90 \mathrm{~mm}$. The mean annual temperature is $26^{\circ} \mathrm{C}$, with an average minimum and maximum of $21^{\circ} \mathrm{C}$ and $31^{\circ} \mathrm{C}$ respectively (2014-2018). This small annual variation on temperature is mainly due to the influence of the sea.

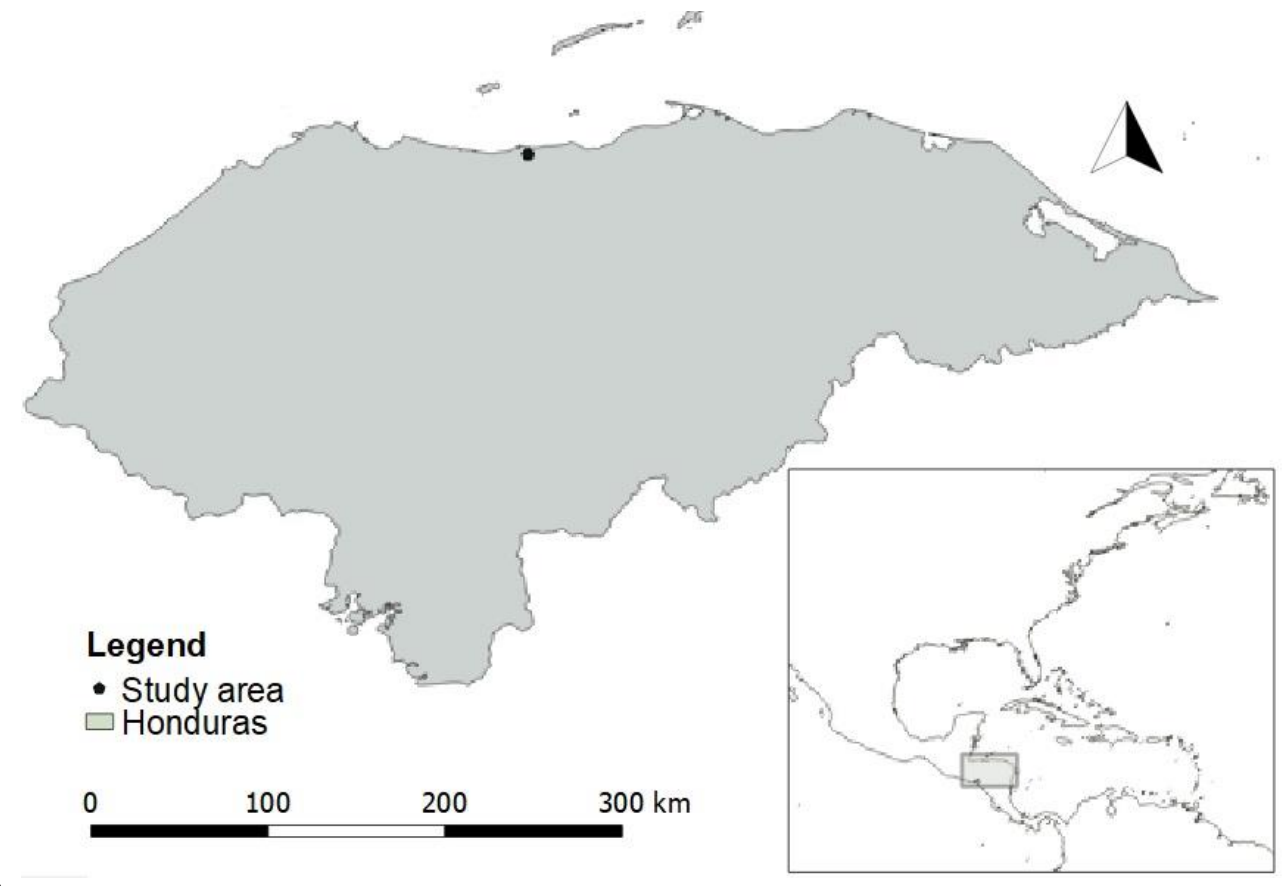

Figure 1. Study area.

\section{Soil sampling and analysis}

In each ecosystem, 10 sampling points were positioned along two transects that were located at least $50 \mathrm{~m}$ apart from each other, and the distance between sampling points were at least $30 \mathrm{~m}$. At each sampling point, a soil pit was opened manually with a depth of $200 \mathrm{~cm}$, and 6 samples from each depth class $(0-20 \mathrm{~cm}, 20-40 \mathrm{~cm}, 40-80 \mathrm{~cm}, 80-120$ $\mathrm{cm}, 120-160 \mathrm{~cm}$, and 160-200 cm) were collected. At each sampling point two samples were collected, one for soil 
organic carbon (SOC) and another for bulk density. A total of 240 samples were collected, of this, 120 samples (2 land uses x 10 pits x 6 depths) were obtained for SOC analysis, and 120 ( 2 land uses x 10 pits x 6 depths) were obtained for bulk density analysis. All samples were collected between the $10^{\text {th }}$ October and $30^{\text {th }}$ of November in 2018 , on days with no rain.

Soil samples collected for SOC analysis were air dried at ambient conditions the same day of collection, once dry, samples were ground and passed through a 2-mm sieve, and they were kept in sealed plastic bags and sent for analysis to the Soil Laboratory at CURLA.

Separate samples for bulk density were collected by hand held, hammer driven, $278 \mathrm{~cm}^{3}$ cylinder core samplers. Cylinders were inserted horizontally into the walls of the soil profile at each designated depth, carefully excavated and cleaned from soil adhering to the ring. Soil samples inside the ring were placed in plastic bags. All samples were dried at $105^{\circ} \mathrm{C}$ for $48 \mathrm{~h}$, and then weighted. Stone content was important at deeper layers at most sites, and it was determined. Roots were negligible and were separated manually.

\section{Organic carbon}

Titration of soil samples was performed using the Walkley-Black $\mathrm{K}_{2} \mathrm{Cr}_{2} \mathrm{O}_{7}$ method (Walkley \& Black, 1934) and SOC value was estimated using the equation proposed by the Mexican Official Norm NOM-021-RECNAT-2000 (Secretaría de Medio Ambiente y Recursos Naturales, 2002).

\section{Texture}

Particle-size distribution was measured for all sampling points and for all depths, via the Bouyoucos method after pretreatment with sodium hydroxide to disperse soil aggregates.

\section{Bulk density}

Dry soil samples were sieved with a $2 \mathrm{~mm}$ sieve and stones were weighted for correction. Bulk density was calculated with Eq. 1 (Pearson et al., 2007).

$$
B D=\frac{O D W}{C V-\frac{C F}{P D}}
$$

Where, BD: Bulk density of the $<2 \mathrm{~mm}$ fraction $\left(\mathrm{g} \mathrm{cm}^{-3}\right)$, ODW: Oven dry mass of fine fraction $<2 \mathrm{~mm}$ in $\mathrm{g}, \mathrm{CV}$ : Core volume $\left(\mathrm{cm}^{3}\right), \mathrm{CF}$ : Mass of the coarse fragment $(>2 \mathrm{~mm})$ in $\mathrm{g}$, PD: Density of rock fragment $\left(\mathrm{g} \mathrm{cm}^{-3}\right) \mathrm{or} \mathrm{particle}^{-3}$ density given as $2.65 \mathrm{~g} \mathrm{~cm}^{-3}$.

\section{Soil organic carbon (SOC) stock}

SOC data were converted to SOC stock in units of $\mathrm{Mg} \mathrm{C} \mathrm{ha}^{-1}$ (also referred to as inventories or storage) by multiplying the concentration by bulk density, and depth interval, as in Eq. 2 (Pearson et al., 2007), in this equation $\%$ SOC is expressed as a decimal fraction.

$$
\text { SOC }\left(\frac{M g}{h a}\right)=\text { bulk density }\left(\frac{g}{\mathrm{~cm}^{3}}\right) x \operatorname{depth}(\mathrm{cm}) \times \% O C \times 100
$$

Cumulative soil C content $(0-200 \mathrm{~cm})$ was calculated by summing contents for the six depth layers.

\section{Soil organic carbon (SOC) stock in terms of $\mathrm{CO}_{2}$ equivalent per unit area}

To convert the mean SOC stock to $\mathrm{CO}_{2}$ equivalent per unit area the following equation given by IPCC (2003) was applied:

$$
C_{\text {soc }}\left(\frac{e q}{h a}\right)=S O C_{\text {mean }}\left(\frac{M g}{h a}\right) \times \frac{44}{12}
$$

Where, C SOC is the mean SOC in terms of $\mathrm{CO}_{2}$ equivalent ha ${ }^{-1}$, SOC mean is the mean SOC Mg ha ${ }^{-1}, 44 / 12$ is the ratio of molecular weight of $\mathrm{CO}_{2}$ to molecular weight of $\mathrm{C}$.

\section{Statistical analyses}

Normality of data distribution was performed for soil separates, bulk density, organic carbon, and organic carbon stock, for both ecosystems with the Shapiro-Wilk normality test. A two-way analysis of variance (ANOVA-GLM procedure) was performed to test for significant differences with ecosystems and sampling depth as the fixed factors for SOC stock. When differences were significant, multiple post-hoc comparisons of means were tested with Tukey HSD at $\mathrm{p}<0.05$. Correlation analysis was performed with the Pearson test between soil separates and SOC. Data analysis and graphics were performed with RStudio Version 1.2.5033. 


\section{RESULTS}

Soil texture at the study site varied from clay loam and sandy clay loam. In the forest, the texture was clay loam in the upper soil layers and sandy clay loam in the deeper layers; whereas in the pasture, it was sandy clay loam in the uppermost layers, clay loam in the middle, and again sandy clay loam in the deeper layers (Table 1).

Table 1. Soil texture, soil bulk density, and soil organic carbon at different depths, CURLA, Atlántida, Honduras.

\begin{tabular}{llllllll}
\hline Ecosystem & $\begin{array}{l}\text { Soil depth } \\
(\mathbf{c m})\end{array}$ & $\begin{array}{l}\text { Soil bulk density } \\
\left(\mathbf{g ~ c m}^{-3}\right)\end{array}$ & $\begin{array}{l}\text { Soil organic } \\
\left(\mathbf{g ~ k g}^{-1}\right)\end{array}$ & \multicolumn{3}{c}{ Soil separates $(\%)$} & Textural class \\
\cline { 5 - 6 } Forest & $0-20$ & 1.09 & 21.26 & 35.5 & 33.6 & 30.8 & Clay loam \\
& $20-40$ & 1.31 & 6.01 & 33.3 & 31.8 & 34.8 & Clay loam \\
& $40-80$ & 1.44 & 1.81 & 35.2 & 30.0 & 34.8 & Clay loam \\
& $80-120$ & 1.59 & 1.23 & 50.9 & 22.4 & 26.6 & Sandy clay loam \\
& $120-160$ & 1.42 & 0.96 & 49.7 & 23.6 & 26.8 & Sandy clay loam \\
& $160-200$ & 1.58 & 0.96 & 52.3 & 23.2 & 24.6 & Sandy clay loam \\
\hline Pasture & $0-20$ & 1.46 & 12.09 & 48.2 & 24.6 & 27.2 & Sandy clay loam \\
& $20-40$ & 1.53 & 3.16 & 51.9 & 23.5 & 24.6 & Sandy clay loam \\
& $40-80$ & 1.50 & 1.58 & 39.7 & 31.4 & 28.9 & Clay loam \\
& $80-120$ & 1.58 & 1.23 & 39.6 & 31.3 & 29.1 & Clay loam \\
& $120-160$ & 1.49 & 0.92 & 49.0 & 25.5 & 25.5 & Sandy clay loam \\
& $160-200$ & 1.48 & 0.90 & 56.3 & 21.4 & 22.3 & Sandy clay loam \\
\hline
\end{tabular}

Soil organic carbon (SOC) stock was significantly higher $(\mathrm{p}<0.05)$ in the forest ecosystem $\left(89.22 \pm 10.95 \mathrm{Mg} \mathrm{ha}^{-1}\right)$ than under pasture $\left(72.54 \pm 10.03 \mathrm{Mg} \mathrm{ha}^{-1}\right)$ at a depth of $0-200 \mathrm{~cm}$ (Table 2). The magnitude of SOC stock was dependent on the analyzed soil layer. Values decreased significantly with depth ( $p<0.05$, Tukey HSD test) in both ecosystems. Results of multiple post-hoc comparisons ( $p<0.05$ Tukey HSD test) are shown in figure 1 . In the forest ecosystem the SOC stock was $44.84 \mathrm{Mg} \mathrm{ha}^{-1}\left(50.3 \%\right.$ of total) at a depth of $0-20 \mathrm{~cm}$, and it increased to $60.00 \mathrm{Mg} \mathrm{ha}^{-1}$ $(67.26 \%)$ at a depth of $0-40 \mathrm{~cm}$; whereas in the pasture SOC stock was $34.75 \mathrm{Mg} \mathrm{ha}^{-1}(47.91 \%)$ at a depth of $0-20 \mathrm{~cm}$, and $44.41 \mathrm{Mg} \mathrm{ha}^{-1}(61.22 \%)$ at a depth of 0-40 $\mathrm{cm}$ (Table 2).

Table 2. Mean SOC stock and variability at different depths and by ecosystem, CURLA, Atlántida, Honduras.

\begin{tabular}{|c|c|c|c|c|c|}
\hline \multirow[t]{2}{*}{ Ecosystem } & \multirow[t]{2}{*}{ Depth (cm) } & \multicolumn{2}{|c|}{ SOC stock $\left(\mathrm{Mg} \mathrm{ha}^{-1}\right)$} & \multirow[t]{2}{*}{ Variance } & \multirow[t]{2}{*}{$\%$} \\
\hline & & Mean & St. Dev. & & \\
\hline \multirow[t]{6}{*}{ Forest } & $0-20$ & 44.84 & 6.38 & 40.76 & 50.26 \\
\hline & $20-40$ & 15.16 & 3.06 & 9.36 & 16.99 \\
\hline & $40-80$ & 10.19 & 2.96 & 8.73 & 11.43 \\
\hline & $80-120$ & 7.84 & 3.92 & 15.33 & 8.79 \\
\hline & $120-160$ & 5.28 & 3.61 & 13.01 & 5.92 \\
\hline & $160-200$ & 5.90 & 5.72 & 32.70 & 6.62 \\
\hline \multirow[t]{6}{*}{ Pasture } & $0-20$ & 34.75 & 8.34 & 69.49 & 47.91 \\
\hline & $20-40$ & 9.66 & 3.56 & 12.69 & 13.31 \\
\hline & $40-80$ & 9.47 & 2.32 & 5.37 & 13.06 \\
\hline & $80-120$ & 7.75 & 2.14 & 4.60 & 10.69 \\
\hline & $120-160$ & 5.51 & 2.06 & 4.26 & 7.60 \\
\hline & $160-200$ & 5.39 & 2.03 & 4.11 & 7.44 \\
\hline
\end{tabular}

The greater accumulation of SOC stock in the upper layers was due to the high SOC content in both ecosystems (Fig. 2), at a depth of $0-20 \mathrm{~cm}$ SOC were $21.26 \mathrm{~g} \mathrm{~kg}^{-1}$ and $12.09 \mathrm{~g} \mathrm{~kg}^{-1}$ for forest and pasture respectively, and low bulk density values, particularly in the forest. The minimum bulk density, $1.09 \mathrm{~g} \mathrm{~cm}^{-3}$, was found at $0-20 \mathrm{~cm}$ and the maximum value, $1.59 \mathrm{~g} \mathrm{~cm}^{-3}$, was found at $80-120 \mathrm{~cm}$ depth, both in the forest ecosystem (Table 1). The mean BD values at a depth of $0-200 \mathrm{~cm}$ between forest and pasture were significantly different $(\mathrm{p}<0.05)$.

The Shapiro-Wilk normality test indicated that soils separates and SOC were not normally distributed. However, as normality is not required, Pearson correction was performed and reported here. A positive and negative significant correlation was observed between SOC concentration and particle size in the forest ecosystem. For clay a positive correlation was observed $(r=0.17 ; p<0.05)$, for silt also a positive correlation was observed $(r=0.39 ; p<0.05)$, and for sand a negative correlation was observed $(r=-0.29 ; \mathrm{p}>0.05)$. No significant correlations were found between soil particle sizes and SOC in the pasture (Fig. 3).

Mean SOC stock in terms of $\mathrm{CO}_{2}$ equivalents $\left(\mathrm{CO}_{2 \text {-eq }}\right)$ for forest was $327.1 \mathrm{Mg} \mathrm{ha}^{-1} \mathrm{CO}_{2 \text {-eq }}$ and for pasture was 265.9 $\mathrm{Mg} \mathrm{ha}^{-1} \mathrm{CO}_{2 \text {-eq }}$ (Fig. 3). As it is shown in figure 4, at a depth of $0-20 \mathrm{~cm}$ is estimated to have $50 \%$ in the forest (164.4 $\mathrm{Mg} \mathrm{ha}^{-1} \mathrm{CO}_{2 \text {-eq }}$ ) and $48 \%$ in the pasture $\left(127.4 \mathrm{Mg} \mathrm{ha}^{-1} \mathrm{CO}_{2 \text {-eq }}\right)$. 




Figure 2. Box-plot of measured soil organic carbon (SOC) by depth at CURLA, Atlántida, Honduras.

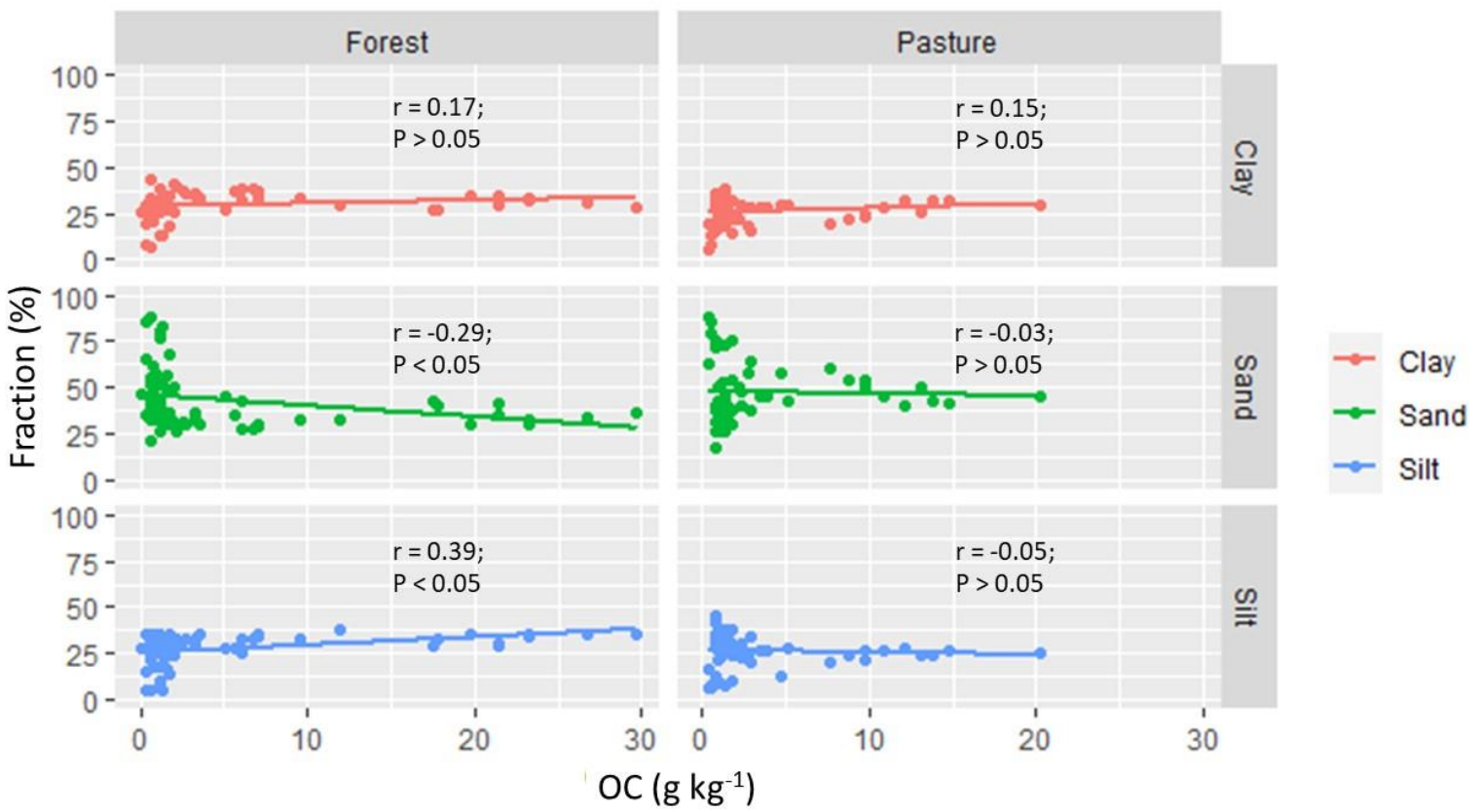

Figure 3. Correlation analysis between SOC and soil separate fraction by land use, at CURLA, Atlántida, Honduras.

\section{DISCUSSION}

Soil organic carbon (SOC) stock

Published data on SOC stock from several studies in the tropics are listed in table 2. Compared to a study undertaken by de Oliveira et al. (2017) in Brazil at a site with annual average of $26^{\circ} \mathrm{C}$ and $2442 \mathrm{~mm} \mathrm{yr}^{-1}$, and at a depth of $0-200 \mathrm{~cm}$, in which they reported SOC stock values of $98.4 \mathrm{Mg} \mathrm{ha}^{-1}$ and $64 \mathrm{Mg} \mathrm{ha}^{-1}$ for forest and pasture respectively, in our study, stock values were $89.2 \mathrm{Mg} \mathrm{ha}^{-1}$ and $72.5 \mathrm{Mg} \mathrm{ha}^{-1}$ for forest and pasture respectively. A study by Chacón et al. (2015) reported a SOC stock of $150.2 \mathrm{Mg} \mathrm{ha}^{-1}$ at a depth of $0-100 \mathrm{~cm}$ in the Atlantic tropical rainforest of Costa Rica and under inceptisols. Jimenez et al. (2007) in a forest consisting of Vochysia guatemalensis Donn. Smith also in Atlantic humid forests of Costa Rica at a depth of 0-50 cm reported $119.2 \mathrm{MgC} \mathrm{ha}^{-1}$, whereas in the pasture they reported $115.6 \mathrm{Mg} \mathrm{C}^{-1}$. In another study in Nicaragua at a site with $1400 \mathrm{~mm} \mathrm{yr}^{-1}$ and under vertisols, Ibrahim et al. (2007) at a depth of 0-100 $\mathrm{cm}$ reported $162.17 \mathrm{Mg} \mathrm{ha}^{-1}$ and $97.3 \mathrm{Mg} \mathrm{ha}^{-1}$ for secondary forest and non-native pasture respectively. Chatterjee et al. (2020) for a site with organic coffee with timber species and mean annual precipitation of $2600 \mathrm{~mm}_{\text {year }}{ }^{-1}$ and mean annual temperature of $22^{\circ} \mathrm{C}$ in Costa Rica, reported a SOC stock of $125 \mathrm{Mg} \mathrm{C}$ ha $^{-1}$ up to a depth of $100 \mathrm{~cm}$ under endoaquepts and endoaquults. These latter values are considerable higher than the values obtained in our study, particularly in the forest and that these values would be much higher at a depth of $200 \mathrm{~cm}$. 
Compared to global estimates for the top $100 \mathrm{~cm}$ of mineral soil $\left(158 \mathrm{Mg} \mathrm{C} \mathrm{ha}^{-1}\right.$ ) our data were lower (Jobbágy \& Jackson, 2000). However, in general, the values reported by de Oliveira et al. (2017) are in the range of our results and in both cases, studies were conducted at $200 \mathrm{~cm}$ depth, and climate is similar, particularly for temperature.

SOC stock depends primarily on the balance between inputs of plant biomass and losses of SOC through decomposition (Jobbágy \& Jackson, 2000; Tian et al., 2015). In tropical regions where high temperatures, high rainfall and intense biological activity, resulting in rapid decomposition of organic matter that is added on the ground (Mielniczuk et al., 2003). In montane humid forests in Ecuador, Paul et al. (2008) reported a SOC pool of $36.4 \mathrm{~g} \mathrm{~kg}^{-1}$ in natural forest soils $(0-10 \mathrm{~cm})$ and in pastures $29.1 \mathrm{~g} \mathrm{~kg}^{-1}$ under sedimentary soils, values higher than those obtained in our study, these differences may be due to climate.

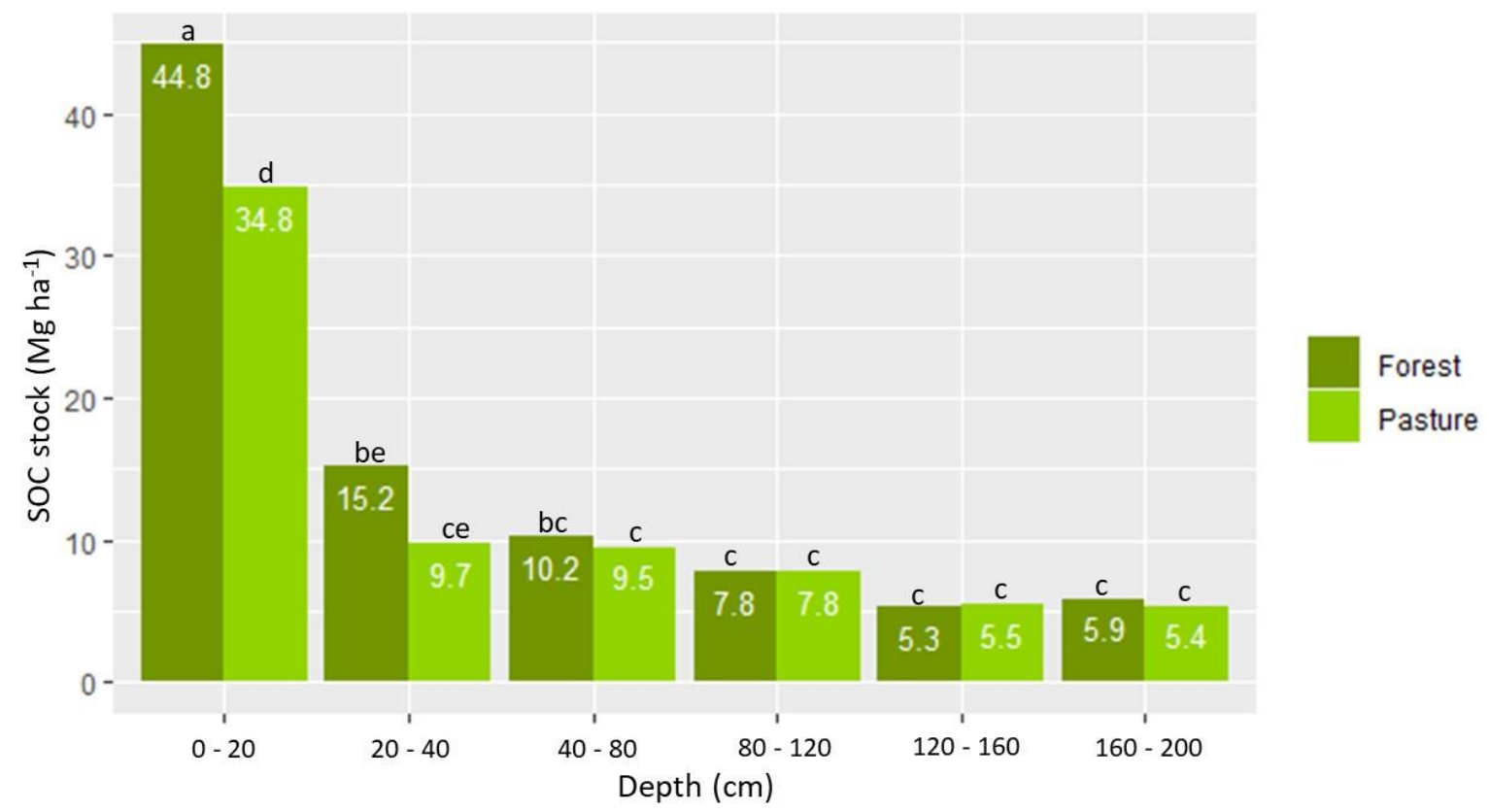

Figure 4. SOC stocks at different depths of soils under a 50 years old secondary forest, and a pasture, at CURLA, Atlántida, Honduras. Values with the same letter are not statistically different according to the Tukey HSD test $(\mathrm{p}=0.05)$.

In our study, the SOC stock was higher in the forest ecosystem as compared to the pasture (Table 2). At a depth of 0-20 $\mathrm{cm}$ in the forest was $44.8 \mathrm{Mg} \mathrm{C} \mathrm{ha}^{-1}$, whereas in the pasture was $34.8 \mathrm{Mg} \mathrm{Cha}^{-1}$, these values are significantly different ( $\mathrm{p}<0.05$ ). At a depth of $20-40 \mathrm{~cm}$, observed value for forest was $15.2 \mathrm{Mg} \mathrm{Cha}^{-1}$ and for pasture $9.7 \mathrm{Mg} \mathrm{Cha}^{-1}$. At deeper layers SOC stock values are much lower and there are no differences in values between the two ecosystems (Fig. 4). The proportion of SOC stock at a depth of $0-40 \mathrm{~cm}$, represents $67 \%$ and $61 \%$ of the total $(0-200 \mathrm{~cm})$ for the forest and pasture respectively. de Oliveira et al. (2017) at a depth 0-40 $\mathrm{cm}$ reported $77 \%$ of the total at a depth of 0-200 $\mathrm{cm}$ SOC stock in spodosols. Chacón et al. (2015) at a depth of 0-40 cm reported 58\% of the total at a depth of 0-100 $\mathrm{cm}$, in their study that percent would probably decrease if they had considered at a depth of 0-200 cm. Batjes (1996) reported a $60 \%$ increase in the global SOC stock when the second meter of soil was included. In our case, if the study had been conducted only to $100 \mathrm{~cm}$, increases of SOC stock would be approximately $27 \%$ and $35 \%$ for forest and pasture respectively if the second meter was included.

In our study, the difference of SOC stock accumulation between forest and pasture is approximately $17 \mathrm{Mg} \mathrm{ha}^{-1}$ and it can be argued that it is mainly affected by vegetation (greater litter input in the forest), followed by the relatively higher clay content in the upper layers in the forest as compared to the pasture (Table 1). However, the amount of temporal input of litter was not addressed. Therefore, specific conclusions pertaining the role of litter input on SOC concentration after 50 years of forest establishment are not defined in this study. Another control worth noticing is soil texture variation with depth (Fig. 5). For sandy tropical soils, Yost \& Hartemink (2019) reported average SOC value of $8 \mathrm{~g} \mathrm{~kg}^{-1}$ for the top $30 \mathrm{~cm}$. In our study, the texture was clay loam, and sandy clay loam and SOC values were 21 and 12 $\mathrm{g} \mathrm{kg}^{-1}$ for forest and pasture respectively, it may indicate the role of clay in retaining more $\mathrm{C}$ in the soil under forest. SOC stock is affected by soil texture and aggregation, and the silt and clay size fractions can protect SOC from decomposition (Gulde et al., 2008; Hassink, 2016). Paul (1984) found that coarse clays and fine silts stabilize the SOC the most, as compared to other soil fractions. Silver et al. (2000) indicates that the SOC accumulation rate in wet forests is $0.51 \mathrm{Mg} \mathrm{C}^{-1}$ year $^{-1}$ over a 100 -year time period, in our study in the forest, this rate is ca. $0.34 \mathrm{Mg} \mathrm{C}^{-1}$ year $^{-1}$. A strong significantly linear relationship between SOC and forest age were reported, at least during the first 100 years after recovery (Silver et al., 2000). SOC monitoring in the study site in the future would be necessary to define if SOC 
continues increasing and when it reaches stabilization. Sayer et al. (2019) demonstrated that interactions between litter inputs and processes involved in the stabilization of SOC are likely to play a key role in tropical forest soil C sequestration in future and they called for further work on the underlying mechanisms.

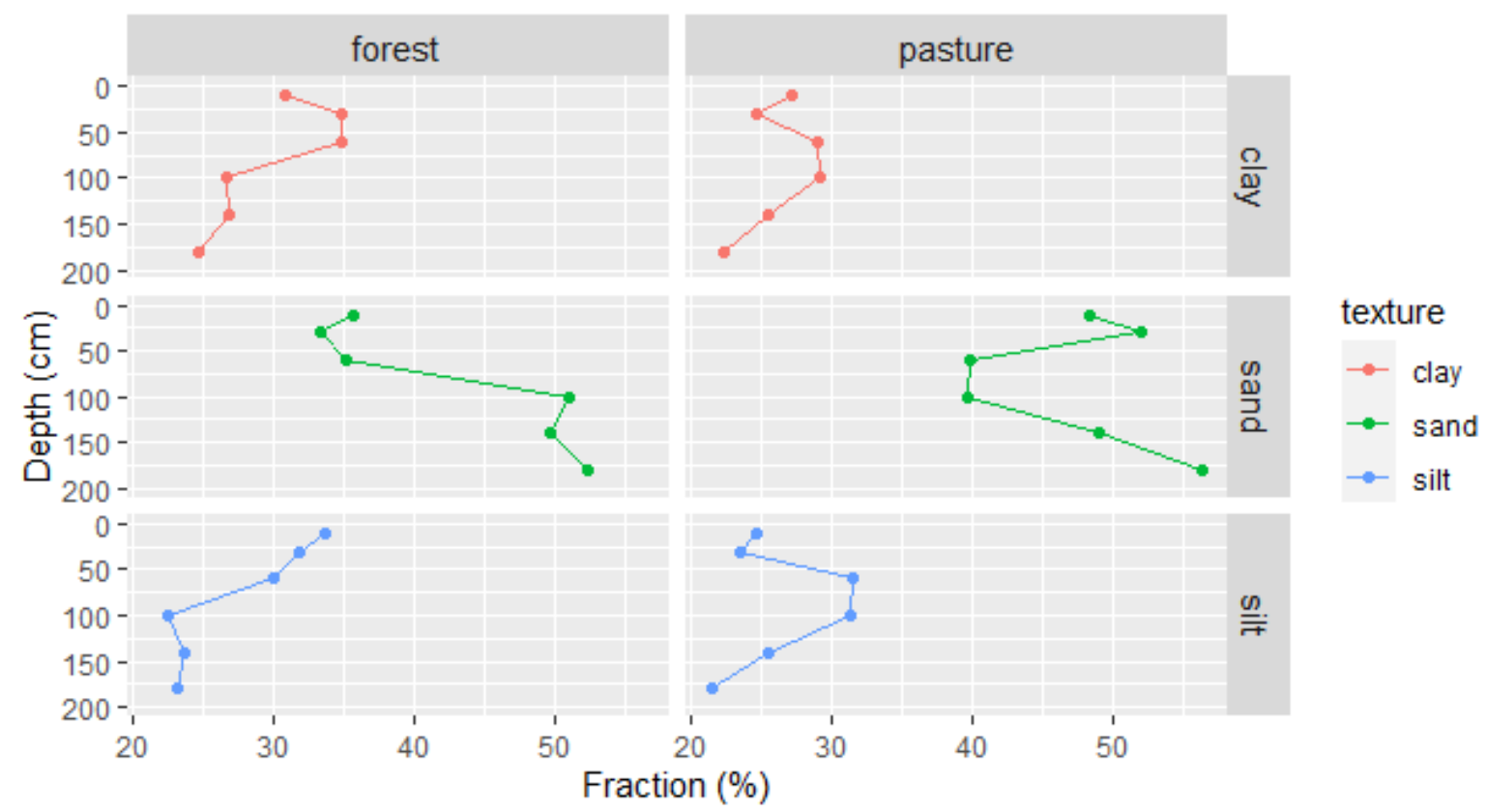

Figure 5. Vertical content of soil separates by land use at CURLA, Atlántida, Honduras.

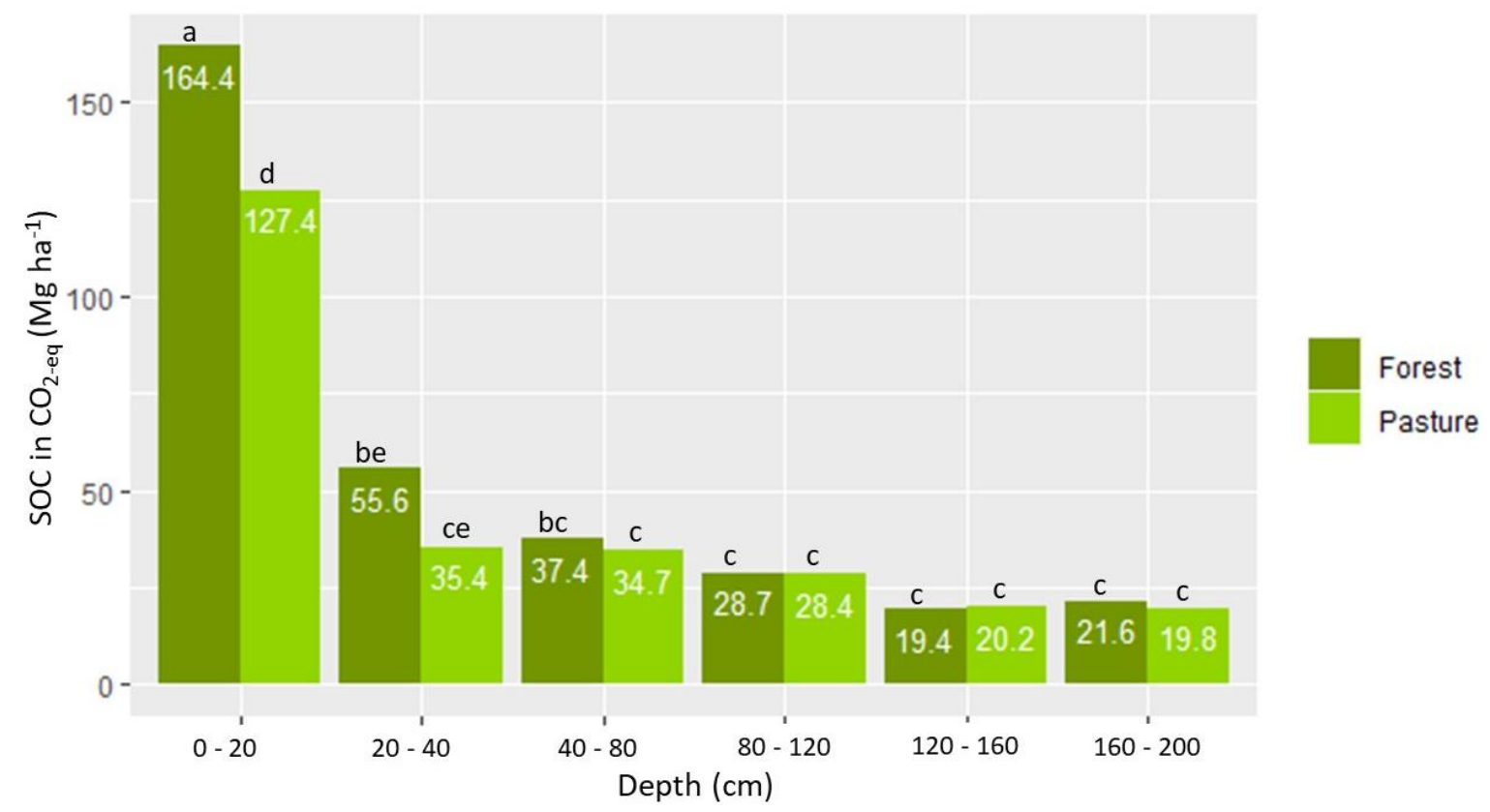

Figure 6. SOC stocks in $\mathrm{CO}_{2}$-equivalents at different depths under a 50 years old secondary forest, and a pasture, at CURLA, Atlántida, Honduras. Values with the same letter are not statistically different according to the Tukey HSD test $(\mathrm{p}=0.05)$.

\section{Soil organic carbon (SOC)}

Similarly, vertical distribution of SOC was higher in the upper layers (Fig. 2) in both ecosystems in accordance with trends reported by Jobbágy \& Jackson (2000). Our findings follow the pattern reported by de Oliveira (2017) for a tropical primary forest, however it is different in which in their study SOC values were higher, the authors reported in units of $\mathrm{g} \mathrm{kg}^{-1}$ the following: $55.1(0-5 \mathrm{~cm}), 37.8(5-10 \mathrm{~cm}), 20.8(10-20 \mathrm{~cm}), 8.2(20-40 \mathrm{~cm}), 5.9(40-60 \mathrm{~cm}), 5.1(60-$ $80 \mathrm{~cm}), 6.3(80-100 \mathrm{~cm}), 2.4(1-160 \mathrm{~cm})$. In our study, average SOC values ranged from $21.26 \mathrm{~g} \mathrm{~kg}^{-1}(0-20 \mathrm{~cm})$ to 0.96 $\mathrm{g} \mathrm{kg}^{-1}(160-200 \mathrm{~cm})$ in the forest, and from $12.09 \mathrm{~g} \mathrm{~kg}^{-1}(0-20 \mathrm{~cm})$ to $0.90 \mathrm{~g} \mathrm{~kg}^{-1}(160-200 \mathrm{~cm})$ in the pasture. At a depth of $200 \mathrm{~cm}$ there is still SOC and it represents approximately $6 \%$ and $7.5 \%$ of the SOC values observed at the uppermost layers $(0-20 \mathrm{~cm})$ of the soil profile for forest and pasture respectively. Global SOC estimations for forests and pastures, Jobbágy \& Jackson (2000) indicate that even up to $300 \mathrm{~cm}$ there is still SOC that needs to be accounted for, even though values are low, and as a result, predictive models would be better calibrated. 
Compared to other studies (Table 3), in our study climate particularly high precipitation seems to play an important role in SOC. Although, Doetterl et al. (2015) indicate that soil geochemistry may be more important for SOC storage than climate, particularly in warm, humid regions, such as tropical forests. In tropical forests, additional fresh plant inputs to the soil could affect SOC stock by promoting the microbial decomposition and turnover of the already stored SOC through the priming effects (Kuzyakov et al., 2000).

Existing SOC stock values in several tropical regions (Table 3) show considerable uncertainty, and this may be because our mechanistic knowledge of $\mathrm{C}$ sequestration is deficient (Schmidt et al., 2011). Tropical forests play an important role in the global C cycle, and yet our knowledge about SOC dynamics and storage in tropical forests is still poor, and these have influence in the large uncertainties in model projections of future $\mathrm{C}$ sequestration (Tian et al., 2015).

Table 3. SOC stock in selected studies conducted in forests and pastures in different sites in tropical Latin America.

\begin{tabular}{lllllll}
\hline Country & Site & Vegetation & Soil type & $\begin{array}{l}\text { Soil depth } \\
(\mathbf{c m})\end{array}$ & $\begin{array}{l}\text { SOC stock } \\
\left(\mathbf{M g ~ h a}^{-\mathbf{1}}\right)\end{array}$ & Reference \\
\hline Mexico & Chiapas & Forest & Leptosol & $0-15$ & 72.57 & Aryal et al., 2018 \\
& Chiapas & Pasture & Leptosol & $0-15$ & 74.37 & Aryal et al., 2018 \\
Costa Rica & Esparza & Secondary forest & Alfisol & $0-100$ & 297.63 & Ibrahim et al., 2007 \\
& Esparza & Pasture & Alfisol & $0-100$ & 139.48 & Ibrahim et al., 2007 \\
& Atlantic & Rainforest & Inceptisol & $0-100$ & 150.2 & Chacón et al., 2015 \\
& Limon & Forest & Andisol & $0-50$ & 119.2 & Jimenez et al., 2007 \\
& Limon & Pasture & Andisol & $0-50$ & 115.6 & Jimenez et al., 2007 \\
\multirow{5}{*}{ Nicaragua } & Matiguas & Secondary forest & Ultisol & $0-30$ & 107 & Fonseca et al., 2012 \\
& Caribbean & Forest plantation & $0-100$ & 162.17 & Ibrahim et al., 2007 \\
& Matiguas & Pasture & Vertisol & $1-100$ & 97.3 & Ibrahim et al., 2007 \\
& Manaus & Primary forest & Oxisol & $0-200$ & 98.4 & de Oliveira, 2015 \\
& Manaus & Pasture & Oxisol & $0-200$ & 64 & de Oliveira, 2015 \\
& Manaus & Forest & Ultisol & $0-200$ & 72.6 & de Oliveira, 2017 \\
& Manaus & Forest & Spodosol & $0-200$ & 81.4 & de Oliveira, 2017 \\
\hline
\end{tabular}

\section{Mean Soil organic carbon (SOC) in terms of $\mathrm{CO}_{2}$ equivalents}

Mean SOC in terms of $\mathrm{CO}_{2}$ equivalents $\left(\mathrm{CO}_{2}\right.$ eq) for a depth 0-200 cm were $327.1 \mathrm{Mg} \mathrm{CO}_{2}$ eq to $265.9 \mathrm{Mg} \mathrm{CO}_{2}$ eq for forest and pasture respectively (Fig. 6). At the upper layers have higher values e.g. $164.4 \mathrm{Mg} \mathrm{CO}_{2}$ eq $(0-20 \mathrm{~cm})$, $55.6 \mathrm{Mg} \mathrm{CO}_{2}$ eq $(20-40 \mathrm{~cm})$, and $37.4(40-80 \mathrm{~cm})$ for the forest, and $127.4 \mathrm{Mg} \mathrm{CO}_{2}$ eq $(0-20 \mathrm{~cm}), 35.4 \mathrm{Mg} \mathrm{CO}_{2}$ eq $(20-$ $40 \mathrm{~cm})$, and $34.7(40-80 \mathrm{~cm})$ for the pasture. These values represent the amount of $\mathrm{CO}_{2}$ gas molecules stored in these ecosystems in the form of SOC. This link between atmospheric $\mathrm{CO}_{2}$ and SOC is currently important from the environmental perspective, but also for the improvement of soil quality (Lal, 2020). If these ecosystems, particularly the forest were converted back to conventional agricultural use, SOC would be considerable reduced through ploughing. This highlights the relevance of appropriate soil management (Lal, 2018) under the implementation of policies such as carbon-emissions trading in tropical countries, i.e. REDD+ projects (Angelsen et al., 2011).

\section{CONCLUSION}

Soil organic carbon (SOC) stock values at a depth of $0-200 \mathrm{~cm}$ in inceptisols under a 50 years old secondary forest and pasture in a tropical humid region in northern Honduras showed lower values than the reported SOC stock values for colder and drier tropical regions.

Most of the SOC is found in the upper layer $(0-20 \mathrm{~cm})$, both in the forest and in the pasture. However, the soil under the forest presents higher SOC values than in the pasture in the upper layers, at deeper layers there are no significant differences in SOC between both ecosystems.

More research is needed in tropical humid regions of the world, particularly Central America, to better understand SOC dynamics and stock, and this would contribute to reduce uncertainties in model projections in $\mathrm{C}$ sequestration for regions with similar climate as in our study.

\section{ACKNOWLEDGEMENTS}

Financial support for this study was provided by the Dirección de Investigación Cientifica y Postgrados (DICYP) from the National Autonomous University of Honduras through the Beca Basica Program. We thank the students (PAC III) from the Agronomy, and Forestry Engineering Departments at UNAH-CURLA for their help with the soil pits. We are also grateful to César Castellon and Jesús Alexis Rodriguez from the Soil Laboratory at UNAH-CURLA for their help in the analysis of soil samples. 


\section{REFERENCES}

Angelsen A., Boucher D., Brown S., Merckx V., Streck C. \& Zarin D. (2011). Guidelines for REDD+Reference Levels: Principles and Recommendations. Meridian Institute, Washington, DC, USA. Retrieved from: https://www.cifor.org/knowledge/publication/5632/

Aryal D.R., Gómez H., Del Carmen N., Ruiz J., Paniagua L.F., Jiménez J.A., Venegas J.A., Pinto R., Ley de Coss A. \& Guevara F. (2018). Potencial de almacenamiento de carbono en áreas forestales en un sistema ganadero. Revista Mexicana de Ciencias Forestales, 9(48): 150-180.

Batjes N.H. (1996). Total carbon and nitrogen in the soils of the world. European Journal of Soil Science, $47:$ 1-163.

Chacón P., Lorenz K., Lal R., Calhoun F. \& Fausey N. (2015). Soil organic carbon in some land uses of Costa Rica. Acta Agricultura Scandinavica, Section B -Soil \& Plant Science, 65 (4): 310-320.

Chambers A., Lal R. \& Paustian K. (2016). Soil carbon sequestration potential of US croplands and grasslands: implementing the 4 per thousand initiative. Journal of Soil and Water Conservation, 71: 68A-74A.

Chatterjee N., Ramachandran Nair PK., Nair VD., Bhattacharjee A., Virginio E., Muschler R. \& Noponen M. (2020). Do coffee agroforestry systems always improve soil carbon stocks deeper in the soil? A Case Study from Turrialba, Costa Rica. Forests, 11(1): 49.

de Oliveira J.D., Luizão F.J., Teixeira W.G., Nogueira E.M., Fearnside P.M. \& Sarrazin M. (2017). Soil Carbon Stocks under Amazonian Forest: Distribution in the Soil Fractions and Vulnerability to Emission. Open Journal of Forestry, 7: 121-142.

Doetterl S., Stevens A., Six J., Merckx R., Van Oost K., Pinto M., Katny A., Muñoz C., Boudin M., Venegas E. \& Boeckx P. (2015). Soil carbon storage controlled by interactions between geochemistry and climate. Nature Geosci, 8: 780-783.

Eswaran H., Van Den Berg E. \& Reich P.F. (1993). Organic carbon in the soils of the world. Soil Science Society of America Journal, 57:192-194.

Fonseca W., Alice F.E. \& Rey-Benayas J.M. (2012). Carbon accumulation in aboveground and belowground biomass and soil of different age native forest plantations in the humid tropical lowlands of Costa Rica. New Forests, 43: 197-211.

Gulde S., Chung H., Amelung W., Chang C. \& Six J. (2008). Soil carbon saturation controls labile and stable carbon pool dynamics. Soil Science Society of America Journal, 72(3): 605-212.

Hassink J. (2016). The capacity of soils to preserve organic C and $\mathrm{N}$ by their association with clay and silt particles. Plant and Soil, 191: 77-87.

Houghton R.A. (2005). Aboveground Forest Biomass and the Global Carbon Balance. Global Change Biology, 11: $945-$ 958.

Ibrahim M., Chacón M., Cuartas C., Naranjo J., Ponce G., Vega P., Casasola F. \& Rojas J. (2007). Almacenamiento de carbono en el suelo y la biomasa arbórea en sistemas de usos de la tierra en paisajes ganaderos de Colombia, Costa Rica y Nicaragua. Agroforesteria en las Americas, 45: 27-46.

IPCC (2003). Good Practices Guidance for Land Use, Land-Use change and Forestry. Institute for Global Environmental Strategies (IGES) for the Intergovernmental Panel on Climate Change (IPCC), Kanagawa, Japan. Retrieved from: https://www.ipcc-nggip.iges.or.jp/public/gpglulucf/gpglulucf_files/GPG_LULUCF_FULL.pdf

IPCC (2018). Global Warming of 1.5 C: Summary for Policymakers. In: Global warming of $1.5^{\circ} \mathrm{C}$. An IPCC Special Report on the impacts of global warming of $1.5^{\circ} \mathrm{C}$ above pre-industrial levels and related global grrenhouse gas emission pathways, in the context of strengthtening the global response to the threat of climate change, sustainable development, and efforts to eradicate proverty. World Meteorological Organization, Geneva, Switzerland. Retrieved from: https://www.ipcc.ch/sr15/chapter/spm/

Jenny H. (1941). Factors of soil formation. McGraw-Hill, New York, New York, USA. 281 p.

Jimenez J.J., Lal R., Leblanc H.A. \& Russo R.O. (2007). Soil organic carbon pool under native tree plantations in the Caribbean lowlands of Costa Rica. Forest Ecology and Management, 241(1-3): 134-144.

Jobbágy E.G. \& Jackson R.B. (2000). The vertical distribution of soil organic carbon and its relation to climate and vegetation. Ecological Applications, 10(2): 423-436.

Kuzyakov Y., Friedel J. K. \& Stahr K. (2000). Review of mechanisms and quantification of priming effects. Soil Biology and Biochemistry, 32: 1485-1498.

Lal R. (2020). Managing soils for negative feedback to climate change and positive impact on food and nutritional security. Soil Science and Plant Nutrition, 66(1): 1-9.

Lal R. (2016). Beyond COP 21: potential and challenges of the "4 per Thousand" initiative. Journal of Soil and Water Conservation, 71: 20A-25A. 
Lal R., Smith P., Jungkunst H.F., Mitsch W.J., Lehmann J., Nair P.K.R., McBratney,A.B., de Moraes Sá J.C., Schneider J., Zinn Y.L., Skorupa A.L.A., Zhang H.-L., Minasny B., Srinivasrao C. \& Ravindranath N.H. (2018). The carbon sequestration potential of terrestrial ecosystems. Journal of Soil and Water Conservation, 73: 145A-152A.

Le Quéré C, Andres R.J., Boden T, Conway T, Houghton R.A., House J.I., Marland G., Peters G.P., van der Werf G.R. \& Ahlström A. (2013). The global carbon budget 1959-2011. Earth System Science Data, 5: 165-185.

Mielniczuk J., Bayer C., Vezzani F.M., Lovato T., Fernandes F.F. \& Debarba L. (2003). Management and Crops and Their Relationship with Carbon and Soil Nitrogen Stocks. In Curi N., Marques J., Guilherme J.L.R, Lima J.M., Lopes A.S. \& Alvarez V.H. (Eds.) Topics in Soil Science. Brazilian Society of Soil Science, Viçosa, pp. $209-248$.

Minasny B., Malone B.P., McBratney A.B., Angers D.A., Arrouays D., Chambers A. \& Field D.J. (2017). Soil carbon 4 per mille. Geoderma, 292: 59-86.

Secretaría de Medio Ambiente y Recursos Naturales. (2002). Norma oficial mexicana NOM-021-SEMARNAT-2000. Diario Oficial, 2da. sección, 31/12/2002. México D. F. México. Retrieved from: https://biblioteca.semarnat.gob.mx/janium/Documentos/Ciga/libros2009/DO2280n.pdf

Oades J.M. (1988). The retention of organic matter in soils. Biogeochemistry, 5: 33-70.

Paul S., Flessa H., Veldkamp E. \& López-Ulloa M. (2008). Stabilization of Recent Soil Carbon in the Humid Tropics following Land Use Changes: Evidence from Aggregate Fractionation and Stable Isotope Analyses. Biogeochemistry, 87(3): 247-263.

Paul E. A. (1984). Dynamics of soil organic matter. Plant and Soil, 76: 275-285.

Pearson T.R., Brown S.L. \& Birdsey R.A. (2007). Measurement guidelines for the sequestration of forest carbon. General Technical Report (GTR). U.S. Department of Agriculture, Forest Service, Newtown Square, PA.

Post W.M., Emanuel W.R., Zinke P.J. \& Stangenberger A.G. (1982). Soil carbon pools and world life zones. Nature, 298: 156-159.

Powers J.S. \& Schlesinger W.H. (2002). Relationships among soil carbon distributions and biophysical factors at nested spatial scales in rain forests of northeastern Costa Rica. Geoderma, 109: 165-190.

Powers J.S., Corre M.D., Twine T.E \& Veldkamp E. (2011). Geographic bias of field observations of soil carbon stocks with tropical land-use changes precludes spatial extrapolation. PNAS, 108(15): 6318-6322.

Sayer E.J., Lopez-Sangil L., Crawford J.A., Bréchet L.M., Birkett A.J., Baxendale C., Castro B., Rodtassana C., Garnett M.H., Weiss L. \& Schmidt M.W.I. (2019). Tropical forest soil carbon stocks do not increase despite 15 years of doubled litter inputs. Scientific Reports, 9(1): 18030.

Scharlemann J.P., Tanner E.V., Hiederer R. \& Kapos V. (2014). Global soil carbon: understanding and managing the largest terrestrial carbon pool. Carbon Management, 5: 81-91.

Schlesinger W.H. (1977). Carbon balance in terrestrial detritus. Annual Review of Ecology and Systematics, 8: 51-81.

Schmidt M., Torn M., Abiven S., Dittmar T., Guggenberger g., Janssens I., Kleber M., Kögel-Knabner I., Lehmann J., Manning D., Nannipieri P., Rasse D., Weiner S. \& Trumbore S. (2011). Soil organic matter persistence as an ecosystem property. Nature, 477: 49-56.

Silver W.L., Neff J., McGroddy M., Veldkamp E., Keller M. \& Cosme R. (2000). Effects of soil texture on belowground carbon and nutrient storage in a lowland Amazonian forest ecosystem. Ecosystems, 3: 193-209.

Sombroek W.G., Nachtergaele F.O. \& Hebel A. (1993). Amounts, dynamics and sequestering of carbon in tropical and subtropical soils. Ambio, 22: 417-423.

Tian H., Lu C., Yang J., Banger K., Huntzinger D., Schwalm C., Michalak A., Cook R., Ciais P., Hayes D., Huang H., Ito A., Jain A., Lei H., Mao J., Pan P., Post W., Peng S., Poulter B., Ren B., Ricciuto D., Schaefer K., Shi X., Tao B., Wang W., Wei Y., Yang Q., Zhang B. \& Zeng N. (2015). Global patterns and controls of soil organic carbon dynamics as simulated by multiple terrestrial biosphere models: Current status and future directions. Global Biogeochemical Cycles, 29: 775-792.

Walkley A. \& Black A. (1934). An examination of Degtjareff method for determining soil organic matter and a proposed modification of the chromic acid titration method. Soil Science, 37: 29-37.

Weyl R. (1980). Geology of Central America. Gebrüder Borntraeger, Berlin, Germany, 371 p.

Yost J.L. \& Hartemink A.E. (2019). Soil organic carbon in sandy soils: A review. Advances in Agronomy, 158: 218295. 